\title{
Assessment of cancers' diagnostic stage in a Deaf community - survey about 4363 Deaf patients recorded in French units
}

\author{
Vladimir Druel ${ }^{1,2,7^{*}}$, Hélène Hayet ${ }^{3}$, Laetitia Esman ${ }^{4}$, Marie Clavel $^{5}$ and Marie-Eve Rougé Bugat ${ }^{1,6}$ (D)
}

\begin{abstract}
Background: Deaf people represent $0.1 \%$ of the French population and their access to public health campaigns is limited due to their frequent illiteracy and the infrequent use of sign language in campaigns. There is also a lack of general health knowledge in spite of the existence of French Deaf Care Units (UASS). The aim of this study is to assess the average diagnostic stage of cancer in the Deaf Community and discuss deafness as a contributing factor.

Methods: Four thousand three hundred sixty-three Deaf patients recorded in five UASS, 80 diagnosed between 2005/01/01 and 2014/12/31 were selected from medical records and/or ICD-10 coding. Data regarding cancers were extracted, grouped by stage and compared to literature. Statistical significance was tested with Fisher's Exact Test.

Results: Eighty patients were selected. Most cancers were diagnosed at advanced stages: of 11 prostate cancers, 46\% were locally advanced and 18\% were metastatic. (In the general population, this was respectively 3\% and 10.4\% $(p<0.01)$ ). Of six colorectal cancers, 67\% were diagnosed at stage III and 33\% at stage IV. (Respectively 20.6\% and 26. $6 \%(p=0.03)$ in the general population). In contrast, of the 15 breast cancers, 93\% were diagnosed at stages T1-T3 that was earlier than in the general population $(p=0.43)$.

Conclusion: In this study, we observed a delay cancer diagnosis among Deaf people. Complicated and/or nonsystematic screening procedures for cancers would be involved. Which is most likely the result of many factors (communication, medical knowledge). Increasing UASS coverage and health information campaigns in sign language could assist in earlier cancer diagnosis.
\end{abstract}

Keywords: Cancer, Deaf, General practice, Communication, Health inequalities, Delayed diagnosis

\section{Background}

In 2010, the World Health Organization (WHO) estimated that the world population suffering from moderate to severe hearing loss was 360 million, including 32 million children [1] who tended to use sign language more often. In France, an estimated 5.5 million people were suffering from moderate to severe hearing impairment in 2008 (about 9.2\% of the general population). Among those who suffered from deafness before the age of six years, only $1 \%$ (about 51,000 persons) utilized French Sign Language (FSL) instead of French as their main language [2]. These people generally have shared

\footnotetext{
* Correspondence: vladimir.druel@dumg-toulouse.fr

${ }^{1}$ University Department of General Practice, Toulouse-Rangueil Faculty of Medicine, 133 route de Narbonne, 31400 Toulouse, France

${ }^{2}$ Oncology united, Auch Hospital, Allée Marie Clarac, 32008 Auch, France Full list of author information is available at the end of the article
}

the same culture and have been referred to as Deaf [3]. For them, situations of social and cultural exclusion have been common. Indeed, until 1991, the ban of FSL in education led to a severe communication handicap [4]. In 2013, 60 to $80 \%$ of this population was considered illiterate or had imperfect mastery of written language [5] and socioeconomic status deprivation is a significant independent determinant for stage of diagnosis and survival [6-8]. This limits their access to information, including public health prevention campaigns [9-11]. For the most part, the Deaf have had very little general health knowledge [12]. Founded in 1995, the French Deaf Care Units, "Unités d'Accueil et de Soins pour les Sourds" (UASS) have been providing healthcare utilizing FSL [13]. The UASS makes possible to carry out a general practice's consultation (treating and sometimes addressing 
to an organ specialist or oncologist). Since its foundation, a total of 19 UASS have opened throughout France.

This limited access to healthcare could have far-reaching consequences for the Deaf such as delayed cancer diagnosis, with cancer being the leading cause of death in France [14]. As a matter of fact, the worldwide cancer diagnosed population has increased to 35.2 million in 2012 [15] from 28 million in 2008 [16]. In France, social disparities have been observed in access to health care [17]. The government has created a National Cancer Plan to study those disparities and improve access to health care [18]. But no incidence or prevalence data has been published to date, regarding the Deaf population [19].

This study makes an assessment of cancers in deaf people and their diagnostic stage followed medically by five UASS and subsequently compared to the general population.

\section{Methods}

\section{Study design and population}

A descriptive, retrospective, multicentric study was carried out using data, collected during a 10 year period, from five French UASS connected to the University Hospitals of Grenoble, Marseille, Toulouse, Poitiers and Paris. Patients' medical records from Paris and Poitiers were preselected with International Classification of Diseases codes (ICD-10) for cancer, complication of cancer or pre-cancerous lesion [20], while data from Grenoble, Marseille and Toulouse were extracted manually in addition to the utilization of ICD-10 codes. After preselection, the retained records where reviewed manually.

This selection process involved cases of cancer diagnosed between 2005/01/01 and 2014/12/31 in Deaf patients who received medical care at a UASS. There are no socio-demographic criteria of exclusion for the admission in the UASS; it's the only medical unit in France for the Deafs people. Patients without deafness were excluded (even if followed by UASS) as well as patients suffering from pre-cancerous lesions or cancer recurrence. Assessment criteria included demographic elements (sex and age at diagnosis) and cancer characteristics (organ targeted, diagnostic stage, pathology results).

\section{Procedures}

This study used the diagnostic stage of cancer defined by multidisciplinary meetings, or, failing that, the stage reported in the summary of the pathologist. Data were grouped in stages for each family of cancer and compared to the most recent data from the general French population. For example, prostate cancer control data were derived from a French population study dating from 2001 [21]. Regarding breast cancer, reference data were extracted from 2000 to 2010 three French area [22]. For all other cancers the reference study [23] was based on data from PETRI (a cohort analysis concerning the mortality of cancer patients in France between 1994 and 1999 [24]) and the American SEER program taken from 1999 to 2005 (cancer incidence in the USA) [25].

The 3 most frequent cancers (breast, prostate and colo-rectal) were compared to the literature on the general population. It is described in detail in the "Results" section, and was realized to allow better data analysis and appreciation of the results.

\section{Statistical analysis}

A descriptive analysis of the patients' characteristics was conducted, As well as a descriptive analysis of their cancer and his stage of diagnosis. Categorical variables were expressed as percentage frequencies. The significance of the data was confirmed by Fisher's Exact Test (FET) using the programming language $\mathrm{R}$ (version: 3.1 .3 ) with $p<0.05$.

\section{Results}

\section{Characteristics of the population}

The population represented in this study included 4363 people followed in five UASS. Among them, 85 were diagnosed with cancer between 2005/01/01 and 2014/12/31. One patient was excluded because the origin of his cancer was not identified (discovered at an overly advanced stage). Four patients were excluded because of their age, less than 18 years old (possibly related with oncological pathology of childhood or related to a genetic disease possibly related itself to the cancer appearance). Of the $80 \mathrm{pa}-$ tients remaining, 34 were women and 46 were men. The average age of the sample was 54.55 years, ranging between 19 and 88 years of age (Fig. 1).

The cancer distribution included 9 onco-hematologic cases and 71 solid cancers with 10 cases involving metastasis (Table 1). Overall the distribution was different between Deaf and referent populations [21-23] (Table 2). The most represented cancers were breast cancer (with $0.34 \%$ of the 4363 screened deaf people - 15 patients), prostate cancer $(0.25 \%$ - 11 patients), and with the same rates, colo-rectal cancer and basal-cell carcinoma ( $0.18 \%$ - 8 patients).

\section{Cancer's stage in the deaf population compared to general population}

Table 2 showed the cancers with a similar distribution as in the general population and cancers who were diagnosed at later stages such as prostate cancer and colorectal cancer or melanoma.

From the 3 types of cancer most frequent in our study, the first cancer was breast cancer with 15 cases, half of them at a local stage (N0). This is not significantly different from the general population $(p=0,58)$ [22]. We found $6,7 \%$ of metastatic breast cancer in the deaf population and $4,5 \%$ in the general population $(p=0,52)$. This is in favour of a similar repartition of the different stages 


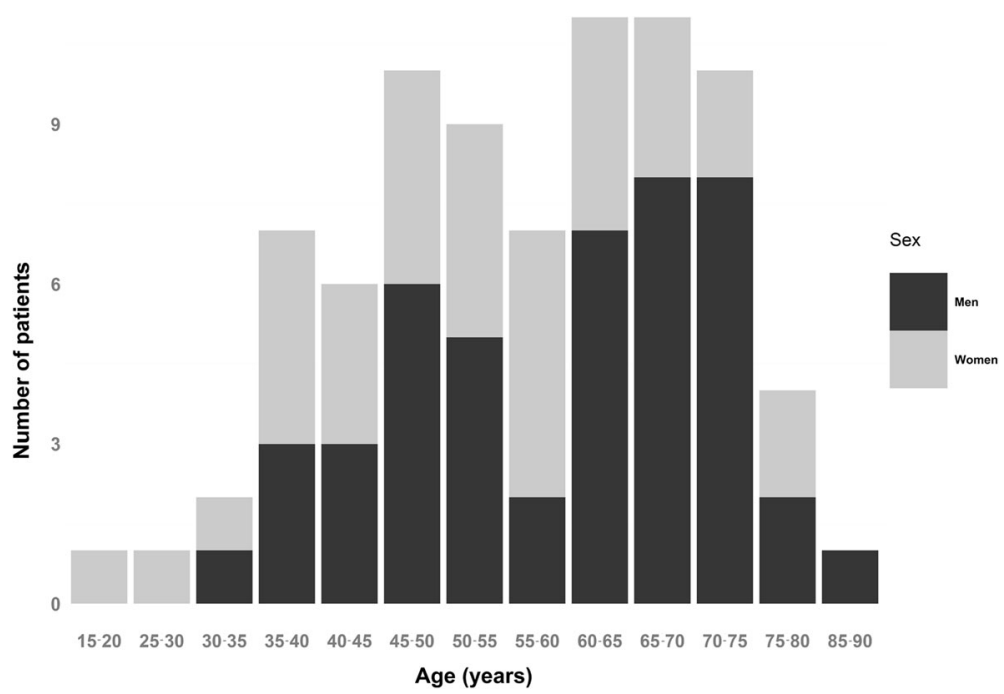

Fig. 1 Distribution of the Deaf patients according to age

of diagnosis, even if the very early stage T1 is slightly more present in the general population (Table 3).

On the contrary, of 11 prostate cancers diagnosed in the studied sample, $64 \%$ were found at an advanced local or metastatic stage. This level of prostate cancer advancement was particularly high since, in the literature data of the general population, only $13 \%$ were diagnosed at this stage [21] $(p=0.04)$.

The six colorectal cancers found in the Deaf sample were primarily far advanced at diagnosis: all are diagnose at stage III and IV when in the general population, 47\% were diagnosed at stage I and II, and the same amount at stage III and IV [24] $(p=0.03)$.

\section{Discussion}

Our work reviewed 4263 patients' in five UASS (Grenoble, Marseille, Paris, Poitiers and Toulouse) in, France and 80 Deafs' cancer patients. Three groups of cancers emerge from the study, depending on early, similar, or late diagnosis, compared to the general population.

\section{Comparison with existing literature}

Of all breast cancers in the study, one was metastatic or T4 (TNM) stage. The diagnosis appeared similar in the Deaf population than in the general population $(p=0.58$; $p=0.52$ ). However, these findings could be linked to the Orsi study [10] which showed the same amount of mammography performed for hearing and Deaf Americans [26]. This could be explained by the simplicity of this screening's availability (a simple prescription, a third party performs the test). Furthermore, French Social Security systematically offers this screening. Increasing mammographic screening coverage reduce late-stage cancer at diagnosis and to reduce socioeconomic disparities
$[27,28]$. It allows the Deaf patient to have a visual understanding of mammography: the FSL sign of mammography is now used in common language so the patient can use it to spread the information within the community.

On the contrary, colo-rectal cancer $(p=0.03)$, prostate cancer $(p=0.04)$ and melanoma were diagnosed at a more advanced stage in the Deaf population than in the general population. A delayed diagnosis for the Deaf was observed in these samples. The colo-rectal cancer's screening test used until 2015 ("Hemoccult II ${ }^{\oplus ")}$ is difficult to explain [29] and even more when there are language barriers or when patients are partially illiterate. This test has to be performed by the patient and if the objective or performance of the test is not understood, completion of the test would be considerably reduced compared to the general population.

For prostate cancer, the rectal examination must be explained prior to being performed. According to Orsi's study, there was more frequent performance of the rectal examination in Deaf people than in the general population observed in the USA [10]. Prostate cancer testing, which is the combination of rectal examination and measure of the prostate specific antigen (PSA), is not a mass screening but is chosen case by case. The decision to undergo prostate cancer screening is made between physician and patient rather than by societal education or medical protocol. This might explain the delayed diagnosis in the Deaf population, as the communication issue remains important. Moreover, we observed that the frequency of PSA testing can be increased by the concern of patients, consequently at their knowledge of the cancer, particularly before the age of 60 [30], and with a higher socioeconomic status [31]. This limited access to the individual screening could have limited the 
Table 1 Assessment of cancers' diagnostic stage in a Deaf Community in this study

\begin{tabular}{|c|c|c|c|c|c|c|}
\hline \multirow[t]{2}{*}{ Cancer (n (\%)) } & \multicolumn{6}{|c|}{ Diagnostic stages } \\
\hline & Stage 0 & Stage I & Stage II & Stage III & Stage IV & $\mathrm{Nl}$ \\
\hline Colorectal $(n=8)$ & 2 & - & - & 4 & 2 & - \\
\hline Melanoma $(n=3)$ & - & - & & 1 & 2 & - \\
\hline Stomach $(n=2)$ & - & - & 1 & - & 1 & - \\
\hline Hodgkin's lymphoma $(n=3)$ & - & - & - & 2 & - & 1 \\
\hline Osteosarcoma $(n=1)$ & - & - & - & 1 & - & - \\
\hline Pancreatic $(n=1)$ & - & - & - & - & 1 & - \\
\hline Lung $(n=3)$ & - & - & 1 & - & 2 & - \\
\hline Kidney $(n=2)$ & - & 1 & - & 1 & - & - \\
\hline \multirow[t]{2}{*}{ Thyroid $(n=3)$} & - & 2 & 1 & - & - & - \\
\hline & T1N0M0 & T2/T3NOMO & $\mathrm{T} 1 / \mathrm{T} 3 \mathrm{~N}+\mathrm{M} 0$ & $\mathrm{~T} 4 \mathrm{~N}+\mathrm{M} 0$ & $\mathrm{M}+$ & $\mathrm{NI}$ \\
\hline \multirow[t]{2}{*}{ Breast $(n=15)$} & 3 & 5 & 6 & - & - & 1 \\
\hline & T1NOMO & T2NOMO & T3/T4NOMO & $N+M+$ & $\mathrm{Nl}$ & \\
\hline \multirow[t]{2}{*}{ Prostate $(n=11)$} & 1 & 1 & 5 & 2 & 2 & \\
\hline & Localized & Regional & Metastatic & & & \\
\hline Oropharyngeal $(n=1)$ & - & 1 & - & & & \\
\hline Basal cell carcinoma $(n=8)$ & 8 & - & - & & & \\
\hline Squamous cell carcinoma $(n=3)$ & 3 & - & - & & & \\
\hline Brain glioma $(n=1)$ & 1 & - & - & & & \\
\hline Cervical $(n=1)$ & 1 & - & - & & & \\
\hline $\mathrm{NHL}^{\mathrm{b}}(n=4)$ & 1 & 2 & 1 & & & \\
\hline Ovarian $(n=1)$ & - & - & 1 & & & \\
\hline Testicular $(n=3)$ & 3 & - & - & & & \\
\hline \multirow[t]{2}{*}{ Uterine $(n=3)$} & 2 & - & 1 & & & \\
\hline & Remarks & & & & & \\
\hline \multirow[t]{2}{*}{ Leukemia $(n=2)$} & $1 \mathrm{AML}^{\mathrm{C}}$ & & & & & \\
\hline & $1 \mathrm{~B}-\mathrm{CLL}^{\mathrm{d}}$ & & & & & \\
\hline Thymoma $(n=1)$ & 1 & & & & & \\
\hline
\end{tabular}

increased over diagnosis (and treatments) performed on the general population for prostate cancer. Screening prostate cancer didn't prove a significative decrease of mortality [32] but the decrease of quality of life [33]. For melanoma, it appears that the instructions for auto-monitoring and prevention involve the same issue of communication.

\section{Strengths and limitations}

There is a recruitment issue: only patients from UASS have been included. Although this recruitment allows the best reflection of a Deaf population without a national register of Deaf people, these units mainly select Deaf people with complex medical or social issues. Another selection bias is that the medical records have been manually selected or selected according to ICD-10 coding. In some cities, the computer systems cannot include all oncology units, which are spread throughout many different hospitals.

In addition, the sample size was small, thus, creating limitations to the results' significance. This is, however, the first study about this topic and the results are relevant for a number of cancers. The comparison to the data of the literature is only indicative.

Second of all, the classification of the data by stage simplifies the information and therefore decreases its accuracy [34], even though it is needed for analysis and comparison. 
Table 2 Comparison of this assessment to baseline studies: only presenting cancers cases (except testicle)

\begin{tabular}{|c|c|c|c|c|}
\hline $\begin{array}{l}\text { Type of cancer } \\
\text { (number of Deaf cases) }\end{array}$ & Stage & $\begin{array}{l}\% \text { observed in the } \\
\text { sample studied (nomber) }\end{array}$ & $\begin{array}{l}\% \text { of the reference } \\
\text { population }\end{array}$ & Baseline studies \\
\hline \multirow[t]{5}{*}{ Colo-rectal $(n=6)$} & I & - & $25.7 \%$ & \multirow{5}{*}{$\begin{array}{l}\text { PETRI (Fr) [24] } \\
\text { (37,413 patients) }\end{array}$} \\
\hline & $\|$ & - & $21.3 \%$ & \\
\hline & III & $67 \%(4)$ & $20.6 \%$ & \\
\hline & IV & $33 \%(2)$ & $26.5 \%$ & \\
\hline & $N D^{a}$ & - & $5.9 \%$ & \\
\hline \multirow[t]{4}{*}{ Melanoma $(n=3)$} & I and || & - & $86.2 \%$ & \multirow{4}{*}{$\begin{array}{l}\text { PETRI (Fr) [24] } \\
\text { (7401 patients) }\end{array}$} \\
\hline & III & $33 \%(1)$ & $3.4 \%$ & \\
\hline & IV & $67 \%(2)$ & $6.4 \%$ & \\
\hline & $N D^{a}$ & - & $4 \%$ & \\
\hline \multirow[t]{5}{*}{ Hodgkin's lymphoma $(n=3)$} & । & - & $81.7 \%$ & \multirow{5}{*}{$\begin{array}{l}\text { PETRI (Fr) [24] } \\
\text { (1544 patients) }\end{array}$} \\
\hline & $\|$ & - & $8.7 \%$ & \\
\hline & III & $67 \%(2)$ & $3.8 \%$ & \\
\hline & IV & - & $3.8 \%$ & \\
\hline & $N D^{a}$ & $33 \%(1)$ & $2.0 \%$ & \\
\hline \multirow[t]{4}{*}{ Non-Hodgkin's lymphoma $(n=4)$} & Localized & $25 \%(1)$ & $30 \%$ & \multirow{4}{*}{$\begin{array}{l}\text { SEER (USA) [25] } \\
(10,224 \text { patients) }\end{array}$} \\
\hline & Regional & $50 \%(2)$ & $15 \%$ & \\
\hline & Metastatic & $25 \%(1)$ & $47 \%$ & \\
\hline & $N D^{a}$ & - & $9 \%$ & \\
\hline \multirow[t]{5}{*}{ Lung $(n=3)$} & I & - & $15.5 \%$ & \multirow{5}{*}{$\begin{array}{l}\text { PETRI (Fr) [24] } \\
\text { (31,557 patients) }\end{array}$} \\
\hline & $\|$ & $33 \%(1)$ & $13.6 \%$ & \\
\hline & III & - & $20 \%$ & \\
\hline & IV & $67 \%(2)$ & $39.4 \%$ & \\
\hline & $N D^{a}$ & - & $11.5 \%$ & \\
\hline \multirow[t]{5}{*}{ Prostate $(n=11)$} & T1N0M0 & $9 \%(1)$ & $27.4 \%$ & \multirow{5}{*}{$\begin{array}{l}\text { «Cancer de la prostate en } \\
\text { France en } 2001 \text { " } 21] \\
\text { (2181 patients) }\end{array}$} \\
\hline & T2NOMO & $9 \%(1)$ & $59.2 \%$ & \\
\hline & T3/T4NOMO & $46 \%(5)$ & $3.0 \%$ & \\
\hline & $\mathrm{N}+\mathrm{M}+$ & $18 \%(2)$ & $10.4 \%$ & \\
\hline & $N D^{a}$ & $18 \%(2)$ & - & \\
\hline \multirow[t]{9}{*}{ Breast $(n=15)$} & $\mathrm{T} 1$ & $33 \%(5)$ & $66 \%$ & \multirow{9}{*}{$\begin{array}{l}\text { Breast cancer incidence: } \\
\text { Decreasing trend in large tumours } \\
\text { in women aged } 50-74 \text { [22] } \\
\text { (28,092 patients) }\end{array}$} \\
\hline & $\mathrm{T} 2+$ & $60 \%(9)$ & $34 \%$ & \\
\hline & $N D^{a}$ & $7 \%(1)$ & - & \\
\hline & No & $53 \%(8)$ & $63 \%$ & \\
\hline & $\mathrm{N}+$ & $40 \%(6)$ & $33 \%$ & \\
\hline & $N D^{a}$ & $7 \%(1)$ & $4 \%$ & \\
\hline & MO & $93 \%(14)$ & $90.5 \%$ & \\
\hline & $\mathrm{M}+$ & $1(7 \%)$ & $4.5 \%$ & \\
\hline & $N D^{a}$ & - & $5 \%$ & \\
\hline \multirow[t]{5}{*}{ Thyroid $(n=3)$} & I & $67 \%(2)$ & $67.9 \%$ & \multirow{5}{*}{$\begin{array}{l}\text { PETRI (Fr) [24] } \\
\text { (6672 patients) }\end{array}$} \\
\hline & $\|$ & $33 \%(1)$ & $6.4 \%$ & \\
\hline & III & - & $9.2 \%$ & \\
\hline & IV & - & $9.2 \%$ & \\
\hline & $N D^{a}$ & - & $7.3 \%$ & \\
\hline Uterine $(n=3)$ & Localized & $67 \%(2)$ & $69 \%$ & $\begin{array}{l}\text { SEER (USA) [25] } \\
\text { (5774 patients) }\end{array}$ \\
\hline
\end{tabular}


Table 2 Comparison of this assessment to baseline studies: only presenting cancers cases (except testicle) (Continued)

\begin{tabular}{lllll}
\hline $\begin{array}{l}\text { Type of cancer } \\
\text { (number of Deaf cases) }\end{array}$ & Stage & $\begin{array}{l}\text { \% observed in the } \\
\text { sample studied (nomber) }\end{array}$ & $\begin{array}{l}\% \text { of the reference } \\
\text { population }\end{array}$ & Baseline studies \\
\hline & Regional & - & $19 \%$ \\
& Metastatic & $33 \%(1)$ & $8 \%$ & $4 \%$ \\
& ND & - & $4 \%$ & \\
\hline
\end{tabular}

${ }^{a}$ ND: Not Definited

Finally, the literature used as reference is old (1994 to 2010) and is derived from different countries (USA, France). However, because of medical progress, better early detection and more comprehensive care during the last years, the delay of cancer diagnosis we found in our study (compared to older study references) has probably been underestimate. New studies should be published using data from the French National Cancer Plan 2009-2013 [18].

We didn't undertake a socio-economic study of our population. However, we know that deaf people in France have a slightly lower socio-economic level than the general population [35] and that it depends on the socio-professional category. Thus far, there is no correlation between deaf and cancer.

Before this study, in the literature we find works on transmission of information for Deaf with cancer, but this study is the first study studying the diagnostic stage of cancer in Deaf population. Despite of the difference of existing structures between countries, there is always a difficulty of access to the information, screening programs and health education of deaf people [36, 37].

\section{Implications into practice}

The Deaf have difficulty accessing medical information including a communication barrier with the practitioner and a lack of education and interpreters $[5,9,10]$. In addition; difficulties of communications remain between general practitioners and oncologists [38]. Exams such as mammography and Papanicolau examination are not understood as well by the Deaf although they undergo these tests as often as people with hearing [10, 26, 39]. The impact of the lack of medical knowledge during a medical consultation is a real problem, even in the UASS where the language barrier is not as prominent. Most Deaf people have a general practitioner and, additionally, a UASS practitioner but the language barrier remains. It is always possible to prescribe a screening test such as mammography or to perform a rectal examination but explanation of the exam is often short and misunderstood. Moreover, it is always more difficult to have a conversation concerning symptomatology between a Deaf and a hearing person. If the practitioner cannot understand the symptomatology then he/she is unable

Table 3 Analysis of the differences of this assessment to baseline studies: only presenting colo-rectal, prostate and breast cancer (more 6 cases)

\begin{tabular}{|c|c|c|c|c|c|}
\hline $\begin{array}{l}\text { Type of cancer } \\
\text { (number of Deaf cases) }\end{array}$ & Stage & $\begin{array}{l}\text { Number observed } \\
\text { in the sample } \\
\text { studied (nomber) }\end{array}$ & $\begin{array}{l}\% \text { of the reference } \\
\text { population }\end{array}$ & $\begin{array}{l}p \text {-values. } \\
\text { fisher's exact test }\end{array}$ & Baseline studies \\
\hline \multirow[t]{3}{*}{ Colo-rectal $(n=6)$} & $|/| \mid$ & - & $47 \%(17584)$ & \multirow[t]{3}{*}{0.03} & \multirow{3}{*}{$\begin{array}{l}\text { PETRI (Fr) [24] } \\
\text { (37,413 patients) }\end{array}$} \\
\hline & III/IV & $100 \%(6)$ & $47 \%(17622)$ & & \\
\hline & $N D^{a}$ & - & $6 \%(2207)$ & & \\
\hline \multirow[t]{3}{*}{ Prostate $(n=11)$} & T1-2/N0 & $18 \%(2)$ & $87 \%$ (1889) & \multirow[t]{3}{*}{0.04} & \multirow{3}{*}{$\begin{array}{l}\text { "Cancer de la prostate en } \\
\text { France en } 2001 \text { » } 21] \\
\text { (2181 patients) }\end{array}$} \\
\hline & $\mathrm{T} 3+$ or $\mathrm{N}+$ or $\mathrm{M}+$ & $64 \%(7)$ & $13 \%(292)$ & & \\
\hline & $N D^{a}$ & $18 \%(2)$ & - & & \\
\hline \multirow[t]{9}{*}{ Breast $(n=15)$} & $\mathrm{T} 1$ & $33 \%(5)$ & $66 \%(18404)$ & \multirow[t]{3}{*}{0.02} & \multirow{9}{*}{$\begin{array}{l}\text { "Breast cancer incidence: } \\
\text { Decreasing trend in large tumours } \\
\text { in women aged 50-74 » [22] } \\
\text { (28,092 patients) }\end{array}$} \\
\hline & $\mathrm{T} 2+$ & $60 \%(9)$ & $34 \%$ (9688) & & \\
\hline & $N D^{a}$ & $7 \%(1)$ & - & & \\
\hline & No & $53 \%(8)$ & $63 \%(17696)$ & \multirow[t]{3}{*}{0.58} & \\
\hline & $\mathrm{N}+$ & $40 \%(6)$ & $33 \%(9205)$ & & \\
\hline & $N D^{a}$ & $7 \%(1)$ & $4 \%(1191)$ & & \\
\hline & MO & $93 \%(14)$ & $90.5 \%$ (25434) & \multirow[t]{3}{*}{1} & \\
\hline & $\mathrm{M}+$ & $1(6.7 \%)$ & $4.5 \%(1268)$ & & \\
\hline & $N D^{a}$ & - & $5 \%(1390)$ & & \\
\hline
\end{tabular}


to recommend the appropriate diagnostic testing. Socioeconomic status must also be considered, as it also affects the survival of the patient $[40,41]$.

Solutions are available to appropriately disseminate information such as language-adapted educational programs, often on video [39, 42-45], ideally bilingual (video and text) [46]. It has been observed that Deaf people are very interested in sharing the information with their community. The FSL educational video [47] may be an excellent addition to the Public Health Educational Campaign. Even better, it could be adapted to the Deaf culture by Deaf people themselves [48]. Increasing general health knowledge (short-term and long-term) [49] would certainly help to diagnose cancers earlier in the Deaf community. A raising awareness and an education of staff medical can allow a better scattering of the information [50].

Raising awareness among medical practitioners as to the communication problem existing between Deaf and hearing people would also improve communication and the identification of their diagnoses and health needs.

This study targeted the Deaf population suffering from cancer and evaluated the stage at initial diagnosis. To further establish if a delayed diagnosis does exist in the general Deaf Population it would be important to perform a case-witness study in order to compare Deaf patients with a paired population.

\section{Conclusion}

After review of 4263 Deaf patients' medical records from the UASS in Grenoble, Poitiers, Paris, Marseille and Toulouse, 80 had a cancer diagnosis. We observed a delay of diagnosis regarding cancers with a complex screening process (colo-rectal cancer), non-systematic screening (prostate cancer and melanoma) and, additionally, with information that was not well codified.

Deafness seems to increase disparity in the access to health care, which could be a factor of bad prognosis in cancers. Many factors could explain this delay such as communication problems between a Deaf patient and a medical practitioner, a lack of general health knowledge within the Deaf Community and the difficult access to written language.

These factors can also become obstacles in the access to the Public Health Campaign and to medical information in general. The UASS helps reduce the language barriers, optimize communication and adapt it to consultations of screening, diagnosis and care of patients. Increasing the population served by the UASS and creating sign language medical information campaigns would improve the lack of general health knowledge in the Deaf community. Mass and individual screenings would also help greatly to an early detection of disease.

\section{Abbreviations}

FET: Fisher's Exact Test; FSL: French Sign Language; ICD-10: International Classification of Diseases (ICD-10); PSA: Prostate Specific Antigen;
UASS: French Deaf Care Units; USA: United States of America; WHO: World Health Organization

\section{Acknowledgments}

To the Deaf Care Units of Grenoble, Marseilles, Paris, Poitiers and Toulouse who gave us access to their data.

To Pascale Grosclaude and Thierry Paricaud for their availability.

Funding

There was no funding received for this study.

\section{Availability of data and materials}

All relevant data and materials are presented in the manuscript.

\section{Authors' contributions}

VD and $\mathrm{HH}$ and MERB conceptualized and design the study. VD and MERB performed the statistical analysis. VD, HH, LE and MC have implemented the study and they have organised the recruitment. All authors contributed in the data acquisition. The article was written by VD, HH and MERB. All co-authors had the opportunity to comment on the analysis and interpretation of the findings and approved the final version of the manuscript.

\section{Authors' information}

MERB is one of the associate editor of the European Journal of General Practice.

Ethics approval and consent to participate

The ethical committee at the general practice department approved this study. It did not require consent from participants as our study analyzed data from usual care. Patients' records were de-identified prior to analysis.

Agreement of the CNIL (National Commission for Information technology and civil Liberties) number: $1838515 \mathrm{v} 0$.

Consent for publication

Not applicable

Competing interests

The authors declare that they have no competing interests.

\section{Publisher's Note}

Springer Nature remains neutral with regard to jurisdictional claims in published maps and institutional affiliations.

\section{Author details}

${ }^{1}$ University Department of General Practice, Toulouse-Rangueil Faculty of Medicine, 133 route de Narbonne, 31400 Toulouse, France. ${ }^{2}$ Oncology united, Auch Hospital, Allée Marie Clarac, 32008 Auch, France. ${ }^{3}$ General practitioner in the medical board of Auch, 'Pion', 32190 Lannepax, France. ${ }^{4}$ Deaf Care Unit, Teaching Hospital of Toulouse-Purpan, Place du Dr Joseph Baylac, 31300 Toulouse, France. ${ }^{5}$ Deaf Care Unit, Teaching Hospital of Grenoble, Avenue Maquis du Grésivaudan, 38700 La Tronche, France. ${ }^{6}$ Inserm U1027, Faculty of Medicine, 37 allées Jules Guesde, 31073 Toulouse, France. ${ }^{7}$ DESC Oncology, 133 route de Narbonne, 31000 Toulouse, France.

Received: 22 May 2017 Accepted: 21 December 2017

Published online: 23 January 2018

References

1. WHO | Deafness and hearing loss - 68th World Health Assembly in Geneva, technical report on hearing loss. WHO. 2015.

2. Laurence Haeusler, Thibaud de Laval, Charlotte Millot. Document de travail: Étude quantitative sur le handicap auditif à partir de l'enquête « HandicapSanté ». Direction de la recherche, des études, de l'évaluation et des statistiques DREES; 2014.

3. Hamm M. Bernard Mottez, Les Sourds existent-ils ? Recherches \& éducations 2008:(1).

4. Conseil Constitutionnel. Loi n 91-73 du 18 janvier 1991 portant dispositions relatives à la santé publique et aux assurances sociales. Sect. Article 33, NOR : SPSX9000173L Jan 16, 1991.

5. Zazove P, Meador HE, Reed BD, Gorenflo DW. Deaf persons' english reading levels and associations with epidemiological, educational, and cultural factors. J Health Commun. 2013;18(7):760-72. 
6. Auluck A, Walker BB, Hislop G, Lear SA, Schuurman N, Rosin M. Socioeconomic deprivation: a significant determinant affecting stage of oral cancer diagnosis and survival. BMC Cancer. 2016;16:569.

7. Du XL, Fang S, Vernon SW, El-Serag H, Shih YT, Davila J, et al. Racial disparities and socioeconomic status in association with survival in a large population-based cohort of elderly patients with colon cancer. Cancer. 2007;110(3):660-9.

8. Liu Z, Zhang K, Risks DXL. Of developing breast and colorectal cancer in association with incomes and geographic locations in Texas: a retrospective cohort study. BMC Cancer. 2016;16:294.

9. Tamaskar P, Malia T, Stern C, Gorenflo D, Meador H, Zazove P. Preventive attitudes and beliefs of deaf and hard-of-hearing individuals. Arch Fam Med. 2000:9(6):518-25. discussion 526

10. Orsi JM, Margellos-Anast H, Perlman TS, Giloth BE, Whitman S. Cancer screening knowledge, attitudes, and behaviors among culturally deaf adults: implications for informed decision making. Cancer Detect Prev. 2007;31(6):474-9.

11. Allaire C. Informer les personnes sourdes et malentendantes: Partage d'expériences. INPES 2012 [Internet]. [cited 2015 Aug 12]. Available from: http://inpes.santepubliquefrance.fr/CFESBases/catalogue/detaildoc. asp? numfiche=1414.

12. Pollard RQ, Barnett $\mathrm{S}$. Health-related vocabulary knowledge among deaf adults. Rehabil Psychol. 2009;54(2):182-5.

13. Dagron J. Les Silencieux, Chroniques de vingt ans de médecine avec les Sourds. Paris: Presse Pluriel;2008. p. 284. ISBN : 978-2-9520770-5-7.

14. Binder-Foucard F, Belot A, Delafosse P, Remontet L, Woronoff AS, Bossard N. Estimation nationale de l'incidence et de la mortalité par cancer en France entre 1980 et 2012: étude à partir des registres des cancers du réseau Francim [Internet]. Saint-Maurice: Institut de veille sanitaire; 2013. Available from: http://opac.invs.sante.fr/index.php?lvl=notice_display\&id=11619

15. Stewart BW, Wild CP. WHO | World Cancer Report 2014 [Internet]. WHO. [cited 2016 Oct 24]. Available from: http://www.who.int/cancer/publications/WRC_2014/en/

16. Boyle $\mathrm{P}$, Levin B, International Agency for Research on Cancer, World Health Organization, editors. World cancer report 2008. Lyon : Geneva: International Agency for Research on Cancer; Distributed by WHO Press; 2008. 510 p.

17. Atherton IM, Evans JMM, Dibben CJL, Woods LM, Hubbard G. Differences in self-assessed health by socioeconomic group amongst people with and without a history of cancer: an analysis using representative data from Scotland. J Cancer Surviv. 2012;6(4):458-67.

18. Vernant J-P, Grünfeld J-P. 3rd cancer plan. Rev Prat. 2013;63(9):1197-8.

19. Sitbon A, Richard J-B. Baromètre santé sourds et malentendants (BSSM n ${ }^{\circ}$ 29). Présentation de l'enquête et premiers résultats. [Internet]. [cited 2015 Aug 22]. Available from: http://inpes.santepubliquefrance.fr/CFESBases/ catalogue/detaildoc.asp?numfiche $=1505$.

20. World Health Organization. ICD-10: International Statistical Classification of Diseases and Related Health Problems. 10th Revision. 2010. [Internet]. WHO. Available from: http://www.who.int/classifications/icd//CD10Volume2_en_2010.pdf

21. Jegu J, Tretarre B, Velten M, Guizard A-V, Danzon A, Buemi A, et al. Prostate cancer management and factors associated with radical prostatectomy in France in 2001. Prog Urol. 2010;20(1):56-64.

22. Molinié F, Delacour-Billon S, Tretarre B, Delafosse P, Seradour B, Colonna M. Breast cancer incidence: decreasing trend in large tumours in women aged 50-74. J Med Screen. 2016;24(4):189-94.

23. Mazeau-Woynar V, Cerf N. Survie attendue des patients atteints de cancer état des lieux 2010 - Ref : RAPSURVIE10 | Institut National Du Cancer [Internet]. [cited 2014 Mar 12]. Available from: http://www.e-cancerfr/ content/download/96009/1022035/file/RAPSURVIE10.pdf.

24. Chinaud F, Slota L, Souques M, Asselain B, Blanchon B, Dubois G, et al. Survie à 5 ans des cancers incidents en Ile-de-France - Cohorte 1994-1999. | Base documentaire | BDSP [Internet]. Available from: http://www.bdsp. ehesp.fr/Base/308923/

25. Horner MJ, Ries LAG, Krapcho M, Neyman N, Aminou R, Howlader N, Altekruse SF, Feuer EJ, Huang L, Mariotto A, Miller BA, Lewis DR, Eisner MP, Stinchcomb DG, Edwards BK (eds). SEER Cancer Statistics Review, 1975-2006, National Cancer Institute. Bethesda, MD, http://seer.cancer.gov/csr/1975_2006/, based on November 2008 SEER data submission, posted to the SEER web site, 2009

26. Berman BA, Jo A, Cumberland WG, Booth H, Britt J, Stern C, et al. Breast cance knowledge and practices among D/deaf women. Disabil Health J. 2013;6(4):303-16.

27. Seneviratne S, Lawrenson R, Harvey V, Ramsaroop R, Elwood M, Scott N, et al. Stage of breast cancer at diagnosis in New Zealand: impacts of sociodemographic factors, breast cancer screening and biology. BMC Cancer. 2016;16:129.
28. Miller JW, Royalty J, Henley J, White A, Richardson LC. Breast and cervical cancers diagnosed and stage at diagnosis among women served through the National Breast and cervical cancer early detection program. Cancer Causes Control. 2015;26(5):741-7.

29. Le Breton J, Journy N, Attali C, Le Corvoisier P, Brixi Z, Bastuji-Garin S, et al. Improving participation in colorectal cancer screening: targets for action. Prev Med. 2012;55(5):488-92

30. Hayat Roshanai A, Nordin K, Berglund G. Factors influencing primary care physicians' decision to order prostate-specific antigen (PSA) test for men without prostate cancer. Acta Oncol. 2013;52(8):1602-8.

31. Rundle A, Neckerman KM, Sheehan D, Jankowski M, Kryvenko ON, Tang D, et al. A prospective study of socioeconomic status, prostate cancer screening and incidence among men at high risk for prostate cancer. Cancer Causes Control. 2013;24(2):297-303.

32. Wilt TJ, Brawer MK, Jones KM, Barry MJ, Aronson WJ, Fox S, et al. Radical prostatectomy versus observation for localized prostate cancer. N Engl J Med. 2012:367(3):203-13.

33. Heijnsdijk EAM, Wever EM, Auvinen A, Hugosson J, Ciatto S, Nelen V, et al. Quality-of-life effects of prostate-specific antigen screening. N Engl J Med. 2012;367(7):595-605.

34. Grosclaude P, Bouvier AM, Tretarre B, Delafosse P. Collecte et utilisation des stades de cancers : problèmes posés dans les études en population. Bull Epidémiol Hebd. 2013;(43-44-45):574-80 [Internet]. [cited 2016 Dec 12]. Available from: http://invs.santepubliquefrance.fr//beh/2013/43-44-45/2013_ 43-44-45_4.html

35. Sitbon Audrey, dir. Baromètre santé sourds et malentendants 2011/2012. Saint-Denis: Inpes coll. 2015. p. 296. ISBN 978-2-9161-9245-1.

36. Nolan BAD, Mathos K, Fusco LE, Post EP. Behavioral health providers for persons who are deaf, deafblind, or hard-of-hearing: a National Survey of the structural and process domains of care. Soc Work Public Health. 2015; 30(5):462-72.

37. Kuenburg A, Fellinger $P$, Fellinger J. Health care access among deaf people. J Deaf Stud Deaf Educ. 2016;21(1):1-10.

38. Chicoulaa B, Balardy L, Stillmunkes A, Mourey L, Oustric S, Rouge Bugat M-E. French general practitioners' sense of isolation in the management of elderly cancer patients. Fam Pract. 2016;33(5):551-6.

39. Yao CS, Merz EL, Nakaji M, Harry KM, Malcarne VL, Sadler GR. Cervical cancer control: deaf and hearing Women's response to an educational video. J Cancer Educ. 2012;27(1):62-6.

40. Ramsay SE, Morris RW, Whincup PH, Papacosta AO, Lennon LT, Wannamethee SG. Time trends in socioeconomic inequalities in cancer mortality: results from a 35 year prospective study in British men. BMC Cancer. 2014;14:474.

41. Bryere J, Dejardin O, Bouvier V, Colonna M, Guizard A-V, Troussard X, et al. Socioeconomic environment and cancer incidence: a French populationbased study in Normandy. BMC Cancer. 2014;14:87.

42. Jensen LG, Nakaji M, Harry KM, Gallegos N, Malcarne VL, Sadler GR. Ovarian cancer: deaf and hearing women's knowledge before and after an educational video. J Cancer Educ. 2013;28(4):647-55.

43. Kaskowitz SR, Nakaji MC, Clark KL, Gunsauls DC, Sadler GR. Bringing prostate cancer education to deaf men. Cancer Detect Prev. 2006;30(5):439-48.

44. Sacks L, Nakaji M, Harry KM, Oen M, Malcarne VL, Sadler GR. Testicular cancer knowledge among deaf and hearing men. J Cancer Educ. 2013;28(3):503-8.

45. Harry KM, Malcarne VL, Branz P, Fager M, Garcia BD, Sadler GR. Evaluating a skin cancer education program for the deaf community. J Cancer Educ. 2012;27(3):501-6.

46. Palmer CGS, Boudreault $P$, Berman BA, Wolfson A, Duarte $L$, Venne $V L$, et al. Bilingual approach to online cancer genetics education for deaf American sign language users produces greater knowledge and confidence than English text only: a randomized study. Disabil Health J. 2017;10(1):23-32.

47. Folkins A, Sadler GR, Ko C, Branz P, Marsh S, Bovee M. Improving the deaf community's access to prostate and testicular cancer information: a survey study. BMC Public Health. 2005;5(1):63.

48. Legeay M, Saillard J. Favoriser l'accès à la santé des sourds et malentendants : exemple d'atelier d'éducation aux médias. Santé Publique. 2013:S2(HS2):235-9.

49. NaseriBooriAbadi T, Sadoughi F, Sheikhtaheri A. Improving cancer literacy for the deaf using deaf-tailored educational interventions: a review of the literature. J Cancer Educ. 2017;1-12.

50. Hickey S, Merz EL, Malcarne VL, Gunsauls DC, Huang J, Sadler GR. Breast cancer education for the deaf community in American sign language. Oncol Nurs Forum. 2013;40(3):E86-91. 